\title{
Biological Assessment of Kahana Stream, Island of O'ahu, Hawai'i: An Application of PABITRA Survey Methods ${ }^{1}$
}

\author{
7. M. Fitzsimons, ${ }^{2}$ F. E. Parbam,${ }^{3}$ L. K. Benson,${ }^{4}$ M. G. McRae, ${ }^{2}$ and R. T. Nishimoto ${ }^{5}$
}

\begin{abstract}
Aquatic biologists surveyed Kahana Stream on O'ahu, Hawai'i, during December 2001 and January, March, and May 2002 to provide a background of information before restoring water diverted from the headwaters of the stream since the mid-1920s. Kahana Stream has all but one species of macrofauna common in unaltered Hawaiian streams, but abundance and distribution of amphidromous species differ conspicuously. A single specimen of 'o'opu 'alamo'o (Lentipes concolor) was found near the headwaters; until recently, this species was regarded as extinct on O'ahu. Only two individuals of the freshwater limpet (hïhiwai, Neritina granosa) were found, and the brackish-water limpet (hapawai, Neritina vespertina) was not observed. Construction of the Waiahhole Ditch Tunnel about $80 \mathrm{yr}$ ago reduced the amount of water entering Kahana headwaters, and unimpeded growth of hau (Hibiscus tiliaceus) from the shore into the stream has slowed water movement in the middle and lower sections of the stream and estuary. Reduced flow has resulted in an extension farther inland of certain estuarine and lower-reach species (the prawn Macrobrachium grandimanus and fishes Eleotris sandwicensis and Stenogobius hawaiiensis). Alien fishes and larger invertebrates occur throughout Kahana Stream. Catches of newly hatched fish $(S$. hawaiiensis) and invertebrates (limited to crustaceans) moving downstream toward the ocean were meager. Recruitment of animals moving from the sea into the stream included only crustaceans and a single individual fish (S. hawaiiensis). Benthic algae were considerably more diverse than recorded for other O'ahu streams. Hau removal and extensive trimming at key locations along Kahana Stream should precede the addition of water to the basin to avoid flooding and to enhance beneficial biological effects.
\end{abstract}

\footnotetext{
${ }^{1}$ This research was supported by a grant from the Division of Aquatic Resources and Commission on Water Resource Management, Department of Land and Natural Resources, State of Hawai'i, for research on Hawaiian stream fishes via the Research Corporation of the University of Hawai'i and the U.S. Fish and Wildlife Service Sport Fish Restoration Program, Grant Agreement No. F-14-R. Manuscript accepted 16 April 2004.

${ }^{2}$ Museum of Natural Science, Louisiana State University, Baton Rouge, Louisiana 70803 (e-mail: fitzsimons@lsu.edu, mmcrae@lsu.edu).

${ }^{3}$ School of Natural Resource Sciences, University of Nebraska, Lincoln, Nebraska 68583-0759 (e-mail: jparham2@unl.edu).

${ }^{4}$ Department of Biology, University of Tampa, Tampa, Florida 33606-1490 (e-mail: lbenson@ut.edu).

${ }_{5}^{5}$ Division of Aquatic Resources, 76 Aupuni Street, Hilo, Hawai'i 96720 (e-mail: Robert.T.Nishimoto@ hawaii.gov).
}

Pacific Science (2005), vol. 59, no. 2:273-281

(C) 2005 by University of Hawai'i Press

All rights reserved
Kahana Stream is a prominent feature of the recently renamed Ahupua'a 'O Kahana State Park, a designation that appropriately emphasizes the fact that the valley is the only publicly owned ahupua'a in the state of Hawaici. Kahana Stream and Valley are located on windward $\mathrm{O}^{\prime}$ ahu about halfway between the towns of Kāne'ohe and Lā'ie. The watershed extends from the small village of Kahana near sea level inland to the crest of the Ko'olau Mountains at $\mathrm{Pu}^{6} \mathrm{u}$ Pauao with an elevation of $814 \mathrm{~m}$. Orographic rain averaging about $760 \mathrm{~cm}$ each year at the back of the valley provides continuous flow in Kahana Stream and its tributaries. The flow of water is typically clear, cool, and brisk at inland sites but becomes less clear, warmer, and sluggish in the lower and deeper sections close to the coast. Kahana Stream forms a true estuary in its lower reaches where fresh water mixes with salt water before emptying into a partly 


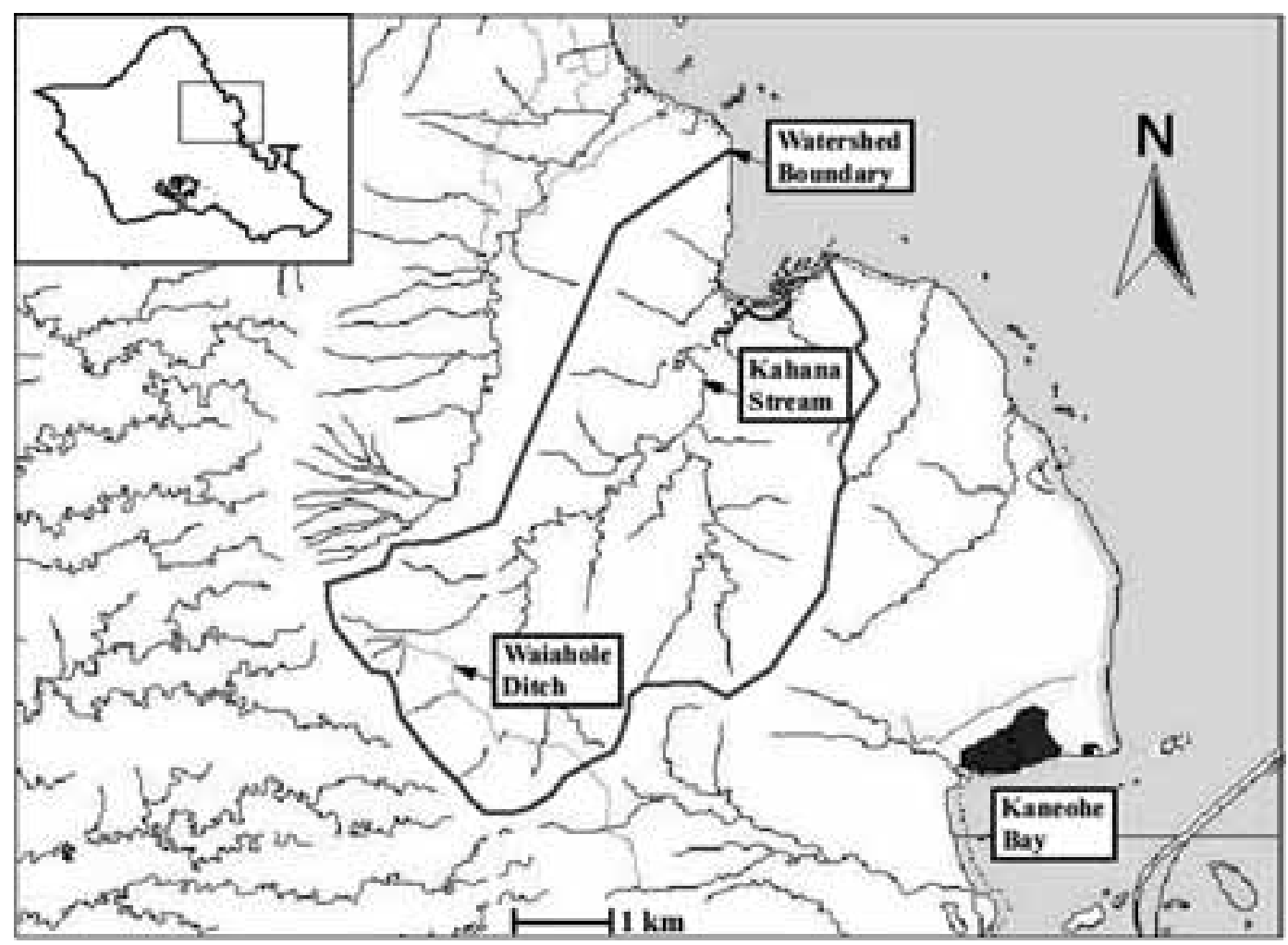

Figure 1. Map of Kahana Valley on the North Shore of O'ahu, Hawai'i.

protected bay. A drainage channel (Waiāhole Ditch) extends across the back of the valley immediately downslope from $\mathrm{Pu}^{6} \mathrm{u}$ Pauao at the extreme western edge of the watershed to $\mathrm{Pu}^{6} \mathrm{u} \mathrm{Ka}^{6}$ aumakua, the peak forming the watershed's southernmost boundary (Figure 1). The ditch captures a substantial amount of runoff from orographic rain, and there is a plan to release some portion of it back into the Kahana headwaters. In this paper we offer certain "educated guesses" about the effect of water return to the basin, but, more importantly, it and particularly the much lengthier report from which it is derived provide a baseline for understanding changes in the stream ecosystem after water volume and flow are increased. This account is drawn from "Biological Assessment of $\mathrm{Ka}$ hana Stream, Island of O'ahu. Final Report" (96 pp.) submitted to the Division of Aquatic Resources and Commission on Water Re- source Management, Hawai'i Department of Land and Natural Resources, in September 2002.

\section{MATERIALS AND METHODS}

Survey procedures are adapted from chapter 7, "Methods for Analyzing Stream Ecosystems" by J. M. Fitzsimons, J. E. Parham, and R. T. Nishimoto, in Biodiversity Assessment of Tropical Island Ecosystems, PABITRA Manual for Interactive Ecology and Management (D. Mueller-Dombois, K. W. Bridges, and C. C. Daehler, eds.) scheduled tentatively for publication in 2005. The book contents are available at http://www.botany.hawaii.edu/pabitra. Stream survey techniques described in the PABITRA manual have been developed during more than a decade of collaboration by the Hawai'i Division of Aquatic Resources and the Louisiana State University Museum 
of Natural Science. Procedures were developed to account for the biological effects of the amphidromous life cycles of stream fishes and larger invertebrates and the frequent flash floods that characterize Hawaiian streams.

A key element of survey data was the identification of animals associated with discrete sections of Kahana Stream and estuary, Huilua Pond, and shore near the stream mouth. Descriptions based on visual observations at each study site included the nature of the water body (riffle, run, pool, cascade), type of shoreline vegetation, extent of the riparian zone, bank stability, water appearance, nutrient enrichment, barriers to fish movement, frequency of pools, extent of canopy cover, and riffle embeddedness. Characterizations of these features are regarded simply as reference conditions because most are determined largely by the time elapsed since the most recent flash flood. In this context, it should be stressed that Hawaiian streams are not stable; they are dynamic. Biological data encompassed species distributions, density and relative abundance (via random and nonrandom underwater transect and point-plot surveys, trapping, netting, and take by hookand-line), downstream drift toward the sea of newly hatched larvae and free-swimming embryos (sensu Balon 1990), recruitment of larvae and juveniles migrating into fresh water from the ocean, behavior associated with feeding and habitat selection by immatures and adults, evidence of reproduction, time budgets, species-specific behavior, parasites in indigenous and alien fishes, and types of benthic algae. The biological data were linked to a Geographic Information System (GIS) program for mapping, identifying species' microhabitat preferences, and assimilating physical and biological information.

Study sites were selected in the lower, middle, and upper sections of Kahana Stream according to basin morphology and the distribution of indigenous animals. Sampling stations in the lowermost stream reach included the seven sites used by Timbol (1972) in a study of the trophic ecology and macrofauna of Kahana estuary. Although not actually part of Kahana Stream, Huilua Fishpond was included in the study because of its proximity to the mouth of the stream on the east side of the bay and its biological and historical significance as an integral part of the Ahupua'a 'O Kahana.

\section{RESULTS AND DISCUSSION}

\section{Species Complements and Distributions}

A list of fishes and larger invertebrates (Table 1) is provided for the principal study sites in and associated with Kahana Stream. Species assemblages occurring near the beach, in the pond, and in the estuary are likely to vary according to season, weather conditions, and movement of marine animals, whether routinely or fortuitously, into and out of waters of lowered salinity. The species occurring farther inland at the middle and upper sections of the stream are much less likely to vary. Although the young of these upstream animals are migratory (Nishimoto and Kuamo'o 1997), adults predictably occupy certain sections of a stream (Fitzsimons and Nishimoto 1991). Individual fishes of certain species inhabit discrete territories used in feeding and spawning for several months (Fitzsimons and Nishimoto 1995) or even for years (Nishimoto and Fitzsimons 1986).

Kahana Stream has nearly a full complement of indigenous aquatic species, but the distribution and relative abundance of these animals differ from their occurrence in similar unaltered streams on windward coasts of the outer islands (stream survey database, Division of Aquatic Resources). Four species usually common in the middle and upper sections of Hawaiian streams (i.e., the gobies Awaous guamensis ['o'opu nākea], Sicyopterus stimpsoni ['o'opu nōpili], and Lentipes concolor ['o'opu alamo'o], and the mountain shrimp Atyoida bisulcata ['ōpae kuahiwi]) were sparse in Kahana Stream even though suitable habitats for each species were available. The sighting of a single individual of 'o'opu alamo'o (Lentipes concolor) in its characteristic habitat in upper Kahana is important because until recently this species was considered extinct on $\mathrm{O}^{\prime}$ ahu (Higashi and Yamamoto 1993). Conversely, the prawn Macrobrachium 
TABLE 1

Aquatic Macrofauna Observed or Collected in or near Kahana Stream during December 2001 and January, March, and May 2002

\begin{tabular}{|c|c|}
\hline Shallow water near beach & Psilogobius mainlandi, Hawaiian shrimp goby \\
\hline $\begin{array}{l}\text { Atherinomorus insularum, 'iao, iau, Hawaiian Islands } \\
\text { silverside }\end{array}$ & $\begin{array}{l}\text { Sarotherodon melanotheron, blackchin tilapia } \\
\text { (introduced) }\end{array}$ \\
\hline Synodus ulae, 'ulae, red lizardfish & Scylla serrata, Samoan crab (introduced) \\
\hline Tylosurus crocodilus, 'aha, hound needlefish & Synodus ulae, 'ulae, red lizardfish \\
\hline Huilua Pond & Valamugil engeli, Marquesan mullet, Australian mullet, \\
\hline Abudefduf abdominalis, maomao, mamo, green & kanda (introduced) \\
\hline damselfish, sergeant major & Mid-Estuary (above bridge) \\
\hline Abudefduf sordidus, kūpīpī, 'o'‘̄̄ nui, blackspot sergeant & Caranx spp. (2), jack crevally family \\
\hline Acanthurus triostegus, manini, convict surgeonfish & Eleotris sandwicensis, 'o'opu 'akupa \\
\hline Ariosoma marginatus, puhi ūhā, tohi, large-eye conger & Kublia xenura, āholehole, Hawaiian flagtail \\
\hline Bothus mancus, pāki'i, 'ui'ui, flowery flounder & Lutjanus fulvus, to'au, flametail snapper (introduced) \\
\hline Carangoides ferdau, ulua, barred jack, blue trevally & Macrobrachium grandimanus, 'ōpae 'oeha'a \\
\hline Diodon hystrix, kōkala, spot-fin porcupinefish & Palaemon debilis, 'ōpae huna, shirasa \\
\hline Kublia xenura, āholehole, Hawaiian flagtail & Scylla serrata, Samoan crab (introduced) \\
\hline $\begin{array}{l}\text { Neomyxus leuciscus, uouoa, acute-jawed mullet, } \\
\text { sharpnose mullet }\end{array}$ & $\begin{array}{l}\text { Synodus ulae, 'ulae, red lizardfish } \\
\text { Upper Estuary (to inland limit of boat traffic) }\end{array}$ \\
\hline $\begin{array}{l}\text { Portunus sanguinolentus, kūhonu, haole crab, blood- } \\
\text { spotted crab }\end{array}$ & $\begin{array}{l}\text { Eleotris sandwicensis, 'o'opu 'akupa } \\
\text { Kublia xenura, āholehole, Hawaiian flagtail }\end{array}$ \\
\hline Synodus ulae, 'ulae, red lizardfish & Macrobrachium grandimanus, 'ōpae 'oeha'a \\
\hline Mouth of Kahana Stream & Macrobrachium lar, Tahitian prawn (introduced) \\
\hline Alpheus sp., snapping shrimp & Poecilia mexicana/sphenops, shortfin molly \\
\hline Kublia xenura, āholehole, Hawaiian flagtail & (introduced) \\
\hline Lutjanus fulvus, to'au, flametail snapper (introduced) & Poecilia reticulata, guppy \\
\hline Macrobrachium grandimanus, 'ōpae 'oeha'a & Scylla serrata, Samoan crab (introduced) \\
\hline Mugil cephalus, 'ama'ama, striped mullet & Xiphophorus belleri, green swordtail (introduced) \\
\hline Mulloides flavolineatus, weke, yellowstripe goatfish & Middle section of Kahana Stream (U.S.G.S. Gauging \\
\hline Palaemon debilis, 'ōpae huna, shirasa & Station at $10 \mathrm{~m}$ elevation) \\
\hline $\begin{array}{l}\text { Portunus sanguinolentus, kūhonu, haole crab, blood- } \\
\text { spotted crab }\end{array}$ & $\begin{array}{l}\text { Kublia xenura, āholehole, Hawaiian flagtail } \\
\text { Macrobrachium grandimanus, 'ōpae 'oeha'a }\end{array}$ \\
\hline Psilogobius mainlandi, Hawaiian shrimp goby & Macrobrachium lar, Tahitian prawn (introduced) \\
\hline Scylla serrata, Samoan crab (introduced) & Stenogobius hawaiiensis, 'o'opu naniha \\
\hline Sphyraena barracuda, kākū, great barracuda & Xiphophorus belleri, green swordtail (introduced) \\
\hline Synodus ulae, 'ulae, red lizardfish & Middle section of Kahana Stream (bamboo grove at \\
\hline Valamugil engeli, Marquesan mullet, Australian mullet, & $45 \mathrm{~m}$ elevation) \\
\hline kanda (introduced) & Awaous guamensis, 'o'opu nākea \\
\hline Lower Kahana Estuary (to Kamehameha Highway & Kublia xenura, āholehole, Hawaiian flagtail \\
\hline bridge) & Macrobrachium grandimanus, 'ōpae 'oeha'a \\
\hline Acanthurus xanthopterus, pualu, yellowfin surgeonfish & Macrobrachium lar, Tahitian prawn (introduced) \\
\hline Alpheus sp., snapping shrimp & Sicyopterus stimpsoni, 'o'opu nōpili \\
\hline Caranx sp., jack crevally family & Xiphophorus belleri, green swordtail (introduced) \\
\hline Eleotris sandwicensis, 'o'opu 'akupa & Upper Kahana Stream (140 m elevation) \\
\hline Grapsus tenuicrustatus, 'a'ama crab & Kublia xenura, āholehole, Hawaiian flagtail \\
\hline Kublia xenura, āholehole, Hawaiian flagtail & Macrobrachium lar, Tahitian prawn (introduced) \\
\hline Lutjanus fulvus, to'au, flametail snapper (introduced) & Upper Kahana Stream (at north terminus of the \\
\hline Macrobrachium grandimanus, 'ōpae 'oeha'a & Waiāhole Ditch Tunnel) \\
\hline Mugil cephalus, 'ama'ama, striped mullet & Atyoida bisulcata, 'ōpae kuahiwi \\
\hline Palaemon debilis, 'ōpae huna, shirasa & Lentipes concolor, 'o'opu 'alamo'o, hi'ukole \\
\hline Poecilia mexicana/sphenops, shortfin molly (introduced) & Macrobrachium lar, Tahitian prawn (introduced) \\
\hline $\begin{array}{l}\text { Portunus sanguinolentus, kūhonu, haole crab, blood- } \\
\text { spotted crab }\end{array}$ & Sicyopterus stimpsoni, 'o‘opu nōpili \\
\hline
\end{tabular}


grandimanus ('ōpae 'oeha'a), a species typical of the lower reaches of streams, had a range extending farther upstream and was more numerous in Kahana Stream than in comparable habitats of other streams. Decades of decreased flow in Kahana Stream via water diversion and the damming effect of hau (Hibiscus tiliaceus) have extended estuarine and lower-reach habitats farther inland, and the species adapted to these conditions have occupied them. The streamwide range of Kublia xenura, an endemic marine fish whose young (āholehole) commonly enter freshwater streams in Hawai'i, was exceeded only by that of the introduced Macrobrachium lar (Tahitian prawn), which occurs from the upper estuary to the upper section of Kahana Stream. Although āholehole are ubiquitous in island streams, these fish do not have a physiological requirement for fresh water at a specific point in their life cycle (Benson and Fitzsimons 2002); however, the overall importance of streams as nurseries and refugia for āholehole has not been determined. It is not known whether the introduced prawn competes with the native congener $M$. grandimanus or feeds on the eggs, young, or adults of naturally occurring stream animals. Neritina granosa (hīhīwai or wī) was represented in all surveys by only two individuals observed in the middle section of Kahana Stream; these limpets are common in the fast-flowing sections of many undiverted Hawaiian streams. The brackish-water limpets Neritina vespertina (hapawai) frequently are found on hard surfaces (rocks, boulders, bridge supports) in estuaries of streams, but none was observed in Kahana Stream.

In Huilua Pond, all species of animals observed or collected were endemic (i.e., they occur naturally in Hawaiian waters). From the mouth of the stream to the upper part of the estuary roughly one-fourth (23-25\%) of the species were introduced. In the middle section of Kahana Stream and at one site in the upper section, alien species composed $30-50 \%$ of the faunal assemblage. Even at the headwaters, one out of four aquatic species was a nonnative.

Markedly different weather conditions (rain and resulting stream discharge) during
December 2001 and March 2002 provided the opportunity to obtain information on animal distributions and water chemistry data in the estuary and stream during periods of both low and high water. At all sites in the estuary, the pronounced disparity in surface versus bottom conductivity during low stream flow in December indicated a well-developed wedge of salt water extending throughout the estuary from the mouth to the upstream limit of boat traffic $(1.6 \mathrm{~km})$. In contrast, conductivity measurements at the water surface and bottom during March indicated that intruding salt water had been pushed seaward by stronger stream flow. A concomitant change in the kinds and numbers of animals present at different sites in the estuary occurred during the two periods of sampling. For the indigenous estuarine prawn Macrobrachium grandimanus, catch per unit effort was nine times greater in traps during March (979 $\mathrm{hr}$ of sampling) than in December $(1,484$ hr). 'O'opu 'akupa, the eleotrid that occurs in lower stream reaches in Hawai'i, was absent in collections in the estuary during December but well represented in March. Conversely, higher-salinity species (i.e., introduced Samoan crabs and to'au) were about 10 times less frequent during the higher flow period. For all fish and invertebrate species combined, catch per unit effort in traps was much greater during the period with high discharge (March) than during low discharge (December). This observed in-stream movement of animals in response to salinity differences in the Kahana estuary may also be expected when additional water is added to the headwaters.

Most biological information and water chemistry data $(\mathrm{pH}$, temperature, salinity, conductivity, and salinity) obtained throughout the length of the Kahana estuary in the current study are remarkably similar to the data recorded by Maciolek (1972) and Timbol (1972) over $30 \mathrm{yr}$ ago, but there is one striking exception. At their recording stations, which we also used, surface and bottom dissolved oxygen concentrations were always very near, at, and sometimes above $100 \%$ saturation. In our work, all readings (surface and bottom at seven sites) were well below satura- 
tion. We suggest that this disparity is directly attributable to heavy siltation, decaying vegetation, retarded primary productivity, decreased aeration effects from flowing water, and other factors that reduce dissolved oxygen because overgrowth of hau (Hibiscus tiliaceus) along stream banks is hindering the flushing action of strong flow and periodic freshets (flash floods).

\section{Animal Migrations}

Drift and recruitment collections reflect, respectively, the downstream movement of free-swimming embryos and larvae of fishes and invertebrates and the upstream movement of animals leaving the ocean and returning to fresh water. Drift indicates a certain stream's potential contribution to the population of plankton offshore that will be available for future recruitment to one or more streams. In Kahana Stream, drift was limited to crustaceans and two species of fishes, Stenogobius hawaiiensis ('o'opu naniha) and Eleotris sandwicensis ('o'opu ākupa). Trapping of animals recruiting into the stream mouth yielded only crustaceans and a single individual of $S$. hawaiiensis.

\section{Parasitology}

Fourteen species of parasites were found by W. F. Font (Southeastern Louisiana University) in 17 species of fishes in Kahana Stream and estuary. The roundworm Camallanus cotti, tapeworm Bothriocephalus acheilognathi, and leech Myzobdella lugubris were the only parasites sufficiently abundant to cause disease in native fishes. All three parasites were introduced into Hawaiian waters along with alien fish species, mostly live-bearers in the family Poeciliidae (represented in Kahana Stream by mollies, guppies, and swordtails). The occurrence of heavy infections of $C$. cotti in Kublia xenura is disconcerting because these euryhaline fish, unlike the gobies limited as adults to fresh water, have the potential for spreading the parasite to other streams. Camallanus cotti and B. acheilognathi do not tolerate the higher salinity in the estuary during the free-living stages of their life cycles. However, the relatively high prevalence of the trematode Opecoeloides kubliae in $K$. xenura from the estuary may provide a model for analyzing parasite dynamics in the estuary in connection with changes in patterns of flow that would occur if water volume in Kahana Stream were augmented.

\section{Algae}

Twenty-six species of macroalgae were identified by A. R. Sherwood (University of Hawai $(i)$ from five collecting sites in the middle and upper sections of Kahana Stream. This taxonomic richness is greater than that currently noted for other streams on windward $\mathrm{O}^{\prime}$ ahu and exceeds the averages for streams on the North American mainland and Caribbean Islands.

\section{The Problem with Hau: An Evaluation and Recommendation}

Whether labeled indigenous (native), alien, or a "naturalized Polynesian introduction" (Sohmer and Gustafson 1987), hau (Hibiscus tiliaceus) is biologically both beneficial and detrimental for Kahana Stream. Intertwined roots and limbs extending into the water sometimes produce a nearly impenetrable tangle that provides cover against predators for $K$. xenura at the mouth of the stream and for the native prawn $M$. grandimanus throughout the estuary. However, unchecked growth of hau has choked down the navigable waterway in the upper estuary and prevented freshets from flushing silt and debris from critical habitats for aquatic animals in the middle and lower sections of Kahana Stream. During flash floods, even relatively small ones, the damming effect of hau often causes localized flooding in the lower part of the valley. In the middle part of the valley during 4 and 6 May 2002, heavy rainfall produced a flash flood that washed out stream banks and knocked down hau trees, some with trunks up to a half meter in diameter. Hau trunks, roots, and branches, along with other debris, formed a temporary dam that shunted large quantities of water into an ancient 'auwai (water-diversion channel used for traditional 
taro agriculture) that flows near the U.S. Geological Survey gauging station (no. 16296500 at $10 \mathrm{~m}$ elevation) on the stream. The 'auwai was severely damaged, and residents expressed concern about the effect of the flood on their livelihood, personal safety, and the potential loss of important archaeological sites. Residents identified the source of the problem to be the dense growth of hau. Residents whose families have lived in Kahana Valley for many generations believe that overgrowth of hau was not a problem before the stream was diverted in the early 1900s. However, it is unknown whether Hawaiians managed the stream to keep it open or whether the greater flow and concomitant stronger flash floods provided a natural control.

Complete removal of hau from the banks of Kahana Stream would be neither beneficial nor practical. Instead, a program of cutting back and removing hau at selected sites could improve stream flow, leave critical cover for aquatic animals, protect the stream banks from erosion, safeguard archaeological sites, and enhance water use for people living in the valley. The initial task would be substantial, and, for the work to be successful, the preliminary effort would need to be followed by continued trimming. Given the current conditions of hau overgrowth in Kahana Stream, the addition of water to the basin would exacerbate problems with flooding.

Judicious trimming and removal of hau likely will assist in realizing the potential biological benefits hoped for by increasing the volume of water entering the headwaters of Kahana Stream. A brisk, continuous flow and occasional flash floods provide several advantages for Hawaiian stream animals (Fitzsimons et al. 1996). Silt, leaf litter, sticks, and other debris are swept from places where aquatic animals live and deposit their eggs. Blooms of filamentous algae that cannot be used as cover or food by stream animals are curtailed by the abrasive action of waterborne sand and gravel. As stream mouths are widened and deepened by freshets, easier access is provided for young animals swimming into and out of the stream mouth during the migratory stages of their amphidromous life cycles; in addition, the migrants are more dispersed and less easily taken by predators. Preliminary studies by the late R. J. F. Smith (University of Saskatchewan) indicate that freshets may be important also by sending into the ocean an olfactory or gustatory stimulus that causes larval stream animals to commence movement inshore and upstream. A hypothesis based on experiments in artificial streams (Fitzsimons et al. 1997) suggests that stronger flow and flash floods may help eliminate or at least reduce numbers of alien fishes that compete with natives for resources and serve as a source of parasites known to have deleterious effects on indigenous species (Font 1997, 1998). In Kahana Stream, additional water and more effective flash floods may redistribute stream animals in patterns that more closely resemble those observed in comparable unaltered streams. The argument here is that the species-specific patterns of distribution commonly seen in undisturbed streams indicate the results of thousands of years of gradually evolved adaptations for living in Hawaiian streams. Restoring these patterns in Kahana Stream presumably would be beneficial for replenishing aquatic species and for maintaining the intrinsic organization of aquatic communities.

Ideally, controlling hau and returning water to Kahana Stream would clean the stream bottom, halt blooms of filamentous algae, facilitate movements of migrating animals, send signals that guide young amphidromous animals as they repopulate the stream, reduce the numbers of alien species, and restore the natural distribution of indigenous stream and estuarine animals. Realistically, the effects are likely to be less definitive. A graded response is more probable. Kahana Stream has a well-developed, natural estuary that will continue to slow water movement. There is a possibility, too, that the amount of water available for placement back into Kahana Stream may be insufficient to bring about susbstantial changes. If discharge is increased at the mouth of Kahana Stream, natural restocking of fishes and invertebrates may continue to be low if only small numbers of potential recruits exist within $\mathrm{Ka}$ hana Bay or in the surrounding ocean waters. 
If this occurs, stocking of adult animals may be necessary. The return of any water to the stream that enhances natural flow patterns should be a positive step toward stream restoration. The added water would provide additional adult habitats and improved migratory pathways. Even if no additional water is placed into Kahana Stream, the control of hau to eliminate damming during freshets should increase the connectivity of the stream, estuary, and ocean waters to the benefit of native amphidromous animals. Additional benefits may also result in terms of decreased flood damage to personal property and archaeological sites.

\section{Extension of PABITRA to Other Islands}

Although a number of biological survey procedures exist for continental streams, PABITRA methods, although drawing from many of these, were intentionally designed and field tested for use in island streams. The format is intended to be flexible and capable of accommodating new sources of information while excluding those that are irrelevant or difficult to use because of local conditions. Indigenous animals (fishes, mollusks, and crustaceans) in Hawaiian streams have relatives throughout Oceania that are strikingly similar in their life histories, habitat selection, behavior, and ecology (Fitzsimons et al. 1996, 2002). For these reasons, we suggest that the PABITRA stream methods, or something like them, are applicable among most oceanic islands of the tropical Pacific and beyond.

\section{ACKNOWLEDGMENTS}

This paper is based on a collaborative field effort involving personnel from the Hawai ${ }^{i}$ Division of Aquatic Resources (G. Higashi, D. Kuamo'o, and R. Nishimoto), the Commission on Water Resource Management (D. Uyeno), Louisiana State University (L. Benson, J. Coleman, M. Fitzsimons, M. McRae, C. Murphy, and A. Styring), University of Nebraska (J. Parham and M. Steinauer), University of Southeastern Louisiana (M. Collins, W. Font, A. Vincent, and J. Willis), and the University of Hawai'i (A. Sherwood). Support in myriad ways was provided by W. Devick (Aquatic Resources), L. Nishioka, E. Sakoda, E. Hirano, D. Nakano, and D. Higa (Water Resource Management), D. Quinn, A. Rogers, M. Yent, T. Palermo, and Kahana staff (Division of State Parks), N. Yen (Division of Conservation and Resource Enforcement), and A. Lee, L. Owan, and G. Anguay (Hawai'i Agribusiness Corp.). We are especially indebted to U. Beirne, S. Greer, B. Shafer, K. Gorai, V. Soga, B. Soga, and other residents of Ahupua'a 'O Kahana for welcoming us into their valley home. We are grateful also to K. Faris and S. Kubota for sharing their expert knowledge on matters both philosophical and practical in respect to Hawaiian streams and their conservation.

\section{Literature Cited}

Balon, E. K. 1990. Epigenesis of an epigeneticist: The development of some alternative concepts on the early ontogeny and evolution of fishes. Guelph Ichthyol. Rev. $1: 1-42$.

Benson, L. K., and J. M. Fitzsimons. 2002. Life history of the Hawaiian fish Kublia sandvicensis as inferred from daily growth rings of otoliths. Environ. Biol. Fishes 65:131-137.

Fitzsimons, J. M., and R. T. Nishimoto. 1991. Behavior of gobioid fishes from Hawaiian fresh waters. Pages 106-124 in W. S. Devick, ed. New directions in research, management, and conservation of Hawaiian freshwater stream ecosystems: Proceedings of the 1990 Symposium on Stream Biology and Fisheries Management, State of Hawai'i, Department of Aquatic Resources, Honolulu.

- 1995. Use of fish behavior in assessing the effects of hurricane Iniki on the Hawaiian island of Kaua'i. Environ. Biol. Fishes 43:39-50.

Fitzsimons, J. M., R. T. Nishimoto, and W. S. Devick. 1996. Maintaining biodiversity in freshwater ecosystems on oceanic islands of the tropical Pacific. Chin. Biodiversity 4 (supplement): 23-27.

Fitzsimons, J. M., H. L. Schoenfuss, and T. C. Schoenfuss. 1997. Significance of unimpeded flows in limiting the transmis- 
sion of parasites from exotics to Hawaiian stream fishes. Micronesica 30:117-125.

Fitzsimons, J. M., J. E. Parham, and R. T. Nishimoto. 2002. Similarities in behavioral ecology among amphidromous and catadromous fishes on the oceanic islands of Hawai' $i$ and Guam. Environ. Biol. Fishes. 65:123-129.

Font, W. F. 1997. Improbable colonists: Helminth parasites of freshwater fishes on an oceanic island. Micronesica 30:105-115. 1998. Parasites in paradise: Patterns of helminth distribution in Hawaiian stream fishes. J. Helminthol. 72:307-311.

Higashi, G. R., and M. N. Yamamoto. 1993. Rediscovery of "extinct" Lentipes concolor (Pisces: Gobiidae) on the island of $\mathrm{O}^{\prime} \mathrm{ahu}$, Hawai'i. Pac. Sci. 47:115-117.

Maciolek, J. A. 1972. Diadromous macrofauna and the Kahana Stream-Estuary ecosystem. Report to Division of State Parks, Department of Land and Natural Re- sources, State of Hawai'i, Honolulu. (Available from Division of State Parks.)

Nishimoto, R. T., and J. M. Fitzsimons. 1986. Courtship, territoriality, and coloration in the endemic Hawaiian freshwater goby, Lentipes concolor. Pages 811817 in T. Uyeno, R. Arai, T. Taniuchi, and K. Matsuura, eds. Indo-Pacific fish biology. Ichthyological Society of Japan, Tokyo.

Nishimoto, R. T., and D. G. K. Kuamo'o. 1997. Recruitment of goby postlarvae into Hakalau Stream, Hawai'i Island. Micronesica 30:41-49.

Sohmer, S. H., and R. Gustafson. 1987. Plants and flowers of Hawai'i. University of Hawai'i Press, Honolulu.

Timbol, A. S. 1972. Trophic ecology and macrofauna of Kahana Estuary, O'ahu. Ph.D. diss., University of Hawai'i at Mānoa, Honolulu. 
